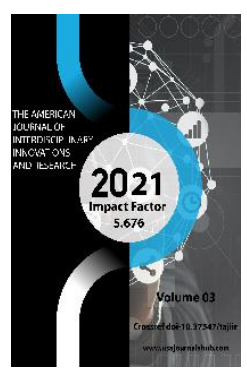

\title{
The Role Of Builder And Building In The Development Of The Country Is Invaluable
}

\author{
Muharram Arabboevna Abdukadirova \\ Teacher Of The Department Of Geodesy, Cartography And Cadastre Of The Ferghana \\ Polytechnic Institute, Uzbekistan
}

Copyright: Original content from this work may be used under the terms of the creative commons attributes 4.0 licence.

\section{ABSTRACT}

This article presents examples, goals, and objectives of new reforms in the construction industry in the Republic of Uzbekistan in recent years. The goals and objectives of the Ministry of Construction and the Strategy were also discussed.

\section{KEYWORDS}

Improvement, beautification, composite, architectural construction, investment.

\section{INTRODUCTION}

It is no secret that in recent years in Uzbekistan, as in all areas, special attention is paid to the development of the construction industry. As a result of decrees and decisions of 
the government and the head of state aimed at further improving the system, the adopted state programs, their implementation, measures to increase the effectiveness of reforms in the sector, the scope of creativity is expanding.

This year, the country has launched the production of aerated concrete blocks, wallpaper, ceramic granite, cast flooring, 600 grades of cement, geosystems, foam blocks, glass crystallite, composite, and chipboard. Uzbekistan is making radical changes in the construction industry.

\section{LITERATURE REVIEW}

However, the beginning of a new era in the construction industry, the identification, recognition, and disclosure of problems in the system, especially in solving them, has not been easy. In total, about 40 laws, decrees, and resolutions regulating the construction industry for 2017-2019 and 2020 have been adopted: 4 in 2017, 13 in 2018, 10 in 2019, and more than 10 by 2020 . . These resolutions and decrees were aimed at radically reforming the problems that had persisted in the system for years.

In particular, the Resolution of the President of the Republic of Uzbekistan dated May 1, 2017 No PP-2936 "On measures to organize the activities of the State Committee for Architecture and Construction of the Republic of Uzbekistan." According to him, the structure of the State Committee for Architecture and Construction has been radically changed and new tasks have been set. The territorial divisions of the Committee have been expanded with additional state units. As a result, Uzshaharsozlik opened branches in 11 regions and Tashkentboshplan in Samarkand, as well as 26 leading project organizations in 13 regions. Tashkent and Samarkand architectural and construction institutes and 14 construction professional colleges were transferred to the committee [1-14].

However, since most of the normative documents in the field, including urban planning rules and building codes, are outdated, obsolete from the old regime, it is still necessary to bring these standards into line with modern requirements. The master plans of the cities, the development of architecturalplanning projects in the villages did not meet the demand at all. In addition, the quality of training in construction and design did not meet the requirements. In particular, there are about 500 vacancies in the system, including 110 vacancies in district (city) departments of architecture and construction, and about 200 vacancies in project organizations. [11-18]. The lack of professional construction companies with all-round potential, their existing material, and technical base, and financial resources were not able to fully cover the growing volume of construction work. In short, the confidence in the Committee was not justified

A presidential decree has been issued to address the problems and delays that have accumulated over the years. Per the Decree of the President of the Republic of Uzbekistan dated April 2, 2018 No PF-5392 "On measures to radically improve the system of public administration in the construction industry", the Ministry of Construction of Uzbekistan was established based on the State Committee for Architecture and Construction. this allowed management in the Construction industry. 


\section{RESULTS}

The strategy of modernization, accelerated and innovative development of the construction industry of the Republic of Uzbekistan for 2021-2025 was approved. The relevant Presidential Decree was adopted on 27 November. The strategy was developed following the Presidential Decree No. PF-5963 of March 13, 2020. Its purpose is to reform the construction industry, aimed at the formation of modern management methods, increasing the investment attractiveness of projects, and the introduction of innovative solutions [1-18]..

The main directions of the document:

- Urban development of the regions and ensuring effective public participation in this process;

- Improving the quality and safety of urban planning activities;

- Ensuring the efficiency, rationality, and transparency of administrative procedures in the field of urban planning, as well as increasing the efficiency of organizations in the construction industry;

- Digitization of urban planning, the introduction of modern information and communication technologies in the industry;

- Improving the system of training, retraining, and advanced training of personnel in the field of urban planning, development of scientific potential.

\section{DISCUSSION}

It should be noted that today, like the rest of the country, the construction industry is entering a new stage of development.
The radical reforms being carried out in our economy, the great changes in our social life, including the tasks set under the Prosperous Village and Prosperous Neighborhood programs, require a completely new way of organizing the development of the sector based on modern science and innovation.

The scale and scope of our creative work in the framework of the state program "Prosperous Village" based on master plans for the improvement of 416 villages in 159 districts of the country in a short period 320 schools, 231 preschools, 148 health It can be seen during the large-scale construction in the building of the public health facility and 77 mahallas, many streets and squares, public places.

\section{Sources used:}

1. ru.wikipedia.org/

2. www.gota.ru/item/4

3. www.astrokras.narod.ru/pub/pakistan 2011.htm

4. https://books.google.ru/books?isbn=5 457283518

5. bourabai.ru/sichuan2008.htm

6. katastrofa.h12.ru/china120508.htm

7. newsru.com/dossier/7684_3.html

\section{REFERENCES}

1. Qodirova D.Sh. Nuriddinov X.N. Binders and construction. Methods of research materials. Textbook. T., Tashkent 2011.

2. Askarov B.A. Building constructions. T., Uzbekistan, 1995. 
3. Akramov H.A. Design of enterprises of the construction materials industry. T., Uzbekistan, 2003.

4. Akramov H.A. Nuritdinov H.N. Manufacture of concrete and reinforced concrete products extraction technology. Textbook. T., National Society of Philosophers of Uzbekistan,2011.

5. Akramov H.A., Nuritdinov H.N. Manufacture of concrete and reinforced concrete products release Textbook, parts I and II. T., Uzbekistan, 2007.

6. Kasimov E. Building materials. .T., Labor 2004.

7. Otakoziyev T. Kasimov E. Mineral binders and their manufactured goods. T., Teacher 1984.

8. Butt Yu.M. Technology of cement and other high-strength materials. M., Publishing house of literature on construction 1964.

9. V.Duda. Semet. M., Stroyizdat 1981.

10. Golovanova L.V. General technology of cement. M., Stroyizdat 1981.

11. A.P.mandrikov.Primery calculation

12. Abdukadorova M.A., Mirzakarimova G.M.«Value of geodetic works in construction of hydrotechnical structures» Academika An international multidisciplinary research journal. 10.06.2020 y. 1307-12

13. Abdukadorova. M.A.,. Mirzakarimova G.M «In orthophotoplane technology photomod mosaic module» International journal of discourse on innovation, integratsion and education.04.11.2020 y.93-97.

14. Abobakirova Z. A. Regulation Of The Resistance Of Cement Concrete With
Polymer Additive And Activated Liquid Medium //The American Journal of Applied sciences. - 2021. - T. 3. - №. 04. - C. 172-177.

15. Goncharova N. I., Abobakirova Z. A., Kimsanov Z. Technological Features of Magnetic Activation of Cement Paste" Advanced Research in Science //Engineering and Technology. - 2019. T. 6. - №. 5 .

16. Кимсанов 3. О., Гончарова Н. И., Абобакирова 3. А. Изучение технологических факторов магнитной активации цементного теста //Молодой ученый. - 2019. - №. 23. - C. 105-106.

17. Muratovich D. S., Shavkatovich N. K. Influence Of Changes In Microclimate Parameters On Human Well-Being And Operational Characteristics Of Building Structures //The American Journal of Engineering and Technology. - 2020. T. 2. - №. 11. - C. 113-117.

18. Davlyatov S. M., Makhsudov B. A. Technologies for producing highstrength gypsum from gypsumcontaining wastes of sulfur productionflotation tailings //ACADEMICIA: An International Multidisciplinary Research Journal. - 2020. - T. 10. - №. 10. - C. 724-728. 